This item is the archived peer-reviewed author-version of:

Returns on foreign investment during the pre-1914 era : the case of Russia

\title{
Reference:
}

Annaert Jan, Buelens Frans, Cuyvers Ludo.- Returns on foreign investment during the pre-1914 era : the case of Russia

European review of economic history - ISSN 1361-4916 - 23:1(2019), p. 72-96

Full text (Publisher's DOI): https://doi.org/10.1093/EREH/HEY004

To cite this reference: https://hdl.handle.net/10067/1577660151162165141 


\section{Returns on foreign investment during the pre-1914 era: the case of Russia}

Jan Annaert (University of Antwerp and Antwerp Management School)

Frans Buelens (University of Antwerp)

Ludo Cuyvers (University of Antwerp and North-West University)

Abstract:

Portfolio investors during 1880-1914 were motivated by the prospect of higher (ex-ante) expected returns and the search for diversification. At the London stock exchange, such overseas portfolios also realised higher (ex-post) returns than domestic portfolios. However, this result cannot be generalised. Higher return expectations for portfolio investments in stocks of companies investing in Russia (listed at the Brussels Stock Exchange) did not realise in the end, mainly due to the exceptional and unforeseeable economic, social, political and geo-political events during the period 1899-1907 and the outbreak of the First World War-these risks being underestimated by investors. 
Before 1914, a strong wave of globalisation swept through Europe. Countries such as Great Britain, France, Belgium, Germany, and the Netherlands were looking abroad for raw materials, markets, and investment opportunities in newly-emerging economies and/or colonial territories. Large numbers of foreign state loans, as well as corporate bonds and stocks from a wide range of countries, among them Russia (Borodkin and Perelman 2011, pp. 96-125), were issued and traded at internationallyoriented stock exchanges, among which these of London, Paris, Amsterdam, Brussels, and Berlin figured prominently. As evidenced by the literature and numerous testimonies (Bonin 2010), portfolio investors were actively in search for such stocks and bonds, mainly for two reasons: higher (ex-ante) expected returns and portfolio diversification. Moreover, Edelstein $(1976,1982)$ found that a portfolio of overseas securities quoted on the London stock exchange not only promised high (exante) returns but also realized higher (ex-post) returns than a domestic portfolio. Goetzmann and Ukhov (2006) and Grossman (2015), using modern portfolio theory and pointing to the low correlation between British and foreign stocks, showed that overseas asset diversification maximized expected returns for British investors. Grossman (2015) also found that the investor's search for diversification helps to explain Britain's capital outflows.

In the present paper, we investigate the return and correlation characteristics of two samples quoted on the Brussels Stock Exchange (BSE): a sample of all stocks of companies investing exclusively in Russia (henceforth "Russian stocks") as compared with a domestic portfolio with stocks of all Belgian companies exclusively investing in Belgium (henceforth "Belgian stocks"). At the pre-1914 BSE, Russian stocks constituted the most important segment of foreign stocks: 146 companies investing exclusively in Russia had securities listed before 1914-some listed only bonds, but no less than 134 companies listed stocks and/or bonds' (Brussels Stock Exchange 1880-1914). In comparison, the Belgian sample contains 650 Belgian companies with stocks during 1880-1914. The BSE was at the time one of the important stock exchanges in the world, making it an interesting research areaii. Together with the Paris stock exchange, the BSE was also among the most important stock exchanges outside Russia for companies investing nearly exclusively in Russia (Crisp 1976, p. 154; Yurick 1959, p. 
III).

Our research of the risk and return characteristics of both samples during the period 1880-1914 allows examining first the corollary, based on Edelstein's results, that higher realized returns on foreign securities spurred investment in Russian stocks. Secondly, our analysis sheds light on whether the less than perfect correlation between Belgian and Russian equity allowed constructing less risky portfolios and improving the risk-return trade-off, since investments should not be analysed in isolation, as pointed out by Goetzmann and Ukhov (2006).

Our analysis focuses on stocks as better reflecting expectations about future corporate profits than corporate and government bonds. Although Russia was a relatively backward country, it was considered to have great potential. To profit from this, solely investing in Russian government bonds was not sufficient as Russia had a good reputation on financial markets, mainly because for decades the tsarist government had punctually paid interest due on its loans $s^{\text {iii }}$. Therefore, Russian government bonds were not considered to be very risky. In contrast, investors had high expectations about Russian stock returns, although being riskier than Russian government bonds. Notwithstanding Edelstein, our results show that ultimately the investors' high return expectations for Russian stocks did not realize (although they were vindicated until 1899). This was due to the exceptional, long lasting and unforeseeable economic, social, political and geo-political events during the period 1899-1907, which caused a high mortality rate among the companies in our sample. Remarkably, however, the survivors succeeded in reconnecting with the high returns of the pre-1899 period. Moreover, it was also due to the outbreak of the First World War. As a result, we find that an ex-post optimal portfolio investing both in Belgian shares and Russian shares listed on the BSE does not perform substantially better than a portfolio that is restricted to buying only Belgian shares. The small proportion of Russian shares in the optimal portfolios we study is in contrast to the popularity that these shares enjoyed in late $19^{\text {th }}$ century Belgium. 
The first section of the paper sketches Russia's history and institutional background during the Tsarist era, as far as relevant for the present study. The second section discusses the company data on Russia and the pull and push factors for investing in Russia. The third section shifts attention to the BSE, which in the period considered was an important financial centre. It is shown that before 1914, Russian stocks consisted of the largest foreign compartment of the BSE, in spite of representing a small, but important, segment of the Russian economy. The fourth section focuses on the data and methodology used. Investment performance is measured by the total return earned on the listed shares, which reflects both capital gains (or losses) and dividend income and is based on stock market prices and dividends. The fifth section divides the Russian foreign investment period into decades and discusses sub-periods in more detail. The stock price index we will use is introduced, which allows the identification of important moments during the period investigated. The Russian sample is then compared with Belgian data for the same period. The sixth section concentrates on the total return on Russian stocks. The seventh section takes risks involved, and the correlation between Russian and Belgian stocks, into account. Section eight summarizes and concludes.

Russia industrialised relatively late. Its defeat in the Crimean War prompted Tsar Alexander II (185581) to embark on a process of catching up with Western European industrialisation. Railway construction (solving the transport issue), a free-trade policy and a number of major reforms, among which the abolition of serfdom in 1861 (creating a free labour market) were the most important ones (Blanchard 2000; Ellison 1965, p. 535; Freeze 1997, pp. 172-7; Gregory 1994, p. 15; Michelson 1965, p.16; Miller 1967, pp. 49-54; Owen 1991, pp. 41-2; Owen 1994, p. 105; Owen 2013, p. 899). The successive Ministers of Finance Nicolai Bunge (1881-6), Ivan Vychnegradsky (1887-92) and Sergei Witte (1892-1903) were particularly strong proponents of industrialisation (and a more active role of the state) (Von Laue 1954; Girault 1972, p. 908). In the 1880s the Tsarist State changed its railroad policy, building also railways for its own account and taking over private lines (Michelson 1965, p. 19; Owen 1991, p. 39; Kahan 1989, p. 39). The financial and banking sector expanded with 
the foundation of the Peasant Bank in 1882 and of the Bank of the Nobility in 1885 (Lyashchenko 1970, p. 467; Falkus 1972, p. 80; Michelson 1965, p. 162). Russia's international trade policy changed into renewed protection, finally leading to the "monster tariffs" of 1891 (Falkus 1972, pp. 56-8). With Russia adopting a protectionist stance, investors had little choice but to support production within the country (Kirchner 1981, p. 374; Kirchner 1986).

In 1892, the year that Tsar Alexander III (1881-94) appointed Sergei Witte as new Minister of Finance, Russia's industrialisation process would receive a dramatic boost. Witte as an advocate of Friedrich List's economic theory on infant industry protection and highly in favour of attracting foreign capital, had a tremendous influence on Russia's economic policy ${ }^{\text {iv }}$ (Michelson 1965, p. 56; Von Laue 1951, pp. 177-8; Witte 1921). During the 1890s, under Witte's supervision, Russia's railway programme intensified. The construction of the Siberian railway, starting in March 1891, greatly stimulated production (Marks 1991). Between 1891 and 1902, the railway network increased by some 27,000 kilometres (Crisp 1976, p. 25; Mosse 1996, p. 105; Michelson 1965, p. 68). The focus of industrialisation shifted from Poland, and the St.Petersburg and Moscow regions towards the South (coal and iron ore regions of Krivoi Rog and Donetz), and from textiles, the main activity of Russian capitalists (Portal 1963), towards huge investments (mainly by foreign capital) in the coal, steel and metal industry as well as in supporting industries (construction, glass) in the South (Kahan 1989, p. 22; Westwood 1965, p. 565; Baykov 1954, p. 141).

One of the main issues for Witte was the convertibility of the ruble. The Russian government was intent on integrating more into the world economy, securing better access into foreign capital markets and becoming more attractive for foreign investment. This necessitated the adoption of the gold standard, which would eliminate exchange rate volatility, reducing uncertainty, as well as increase Russia's prospects of borrowing from abroad and attracting foreign capital (Kahan 1967; Gregory 1979, pp. 379-400). In order to build up gold reserves, exports were encouraged and imports discouraged (Von Laue 1974, p. 145). Abundant gold reserves were considered to be a guarantee of a solid currency, acting as the "best lubricant for the transfer of Western savings and 
skills to Russia" (Gregory 1979, p. 300) and as a means of ultimately acquiring a convertible ruble. The adoption of the gold standard reduced volatility and uncertainty; it reduced the cost of capital, and it allowed the owners of Russian bonds and stocks to convert their coupons in rubles at a fixed exchange rate (Gregory 1979, pp. 391-2). The introduction of the gold standard in 1897 froze the ratio of the credit to gold rubles ${ }^{v}$, respectively, at 3:2, obliging companies whose capital had been expressed in gold to convert to the paper currency at the given conversion rate. This change ensured that stockholders in Europe would not lose one third of their gold-denominated Russian investments as a result of the "hidden devaluation" (Owen 1989, p. 701). No doubt, the introduction of the gold standard made foreign investment in Russia more attractive (Waller 1979; Girault 1999).

The gradual conversion of many different types of Russian loans (Michelson 1965, pp. 58-9), the strong budgetary situation and the introduction of the gold standard were significant developments during the Witte era, strengthening Russia's sound financial and budgetary base (Stepanov 2008). The annual rate of industrial growth increased to 9 per cent during 1894-9 (Crisp 1976, p. 111; Goldsmith 1961). Russia became the place to be. Between 1890 and 1900, total foreign investment in Russian industry increased by 450 per cent (Peeters and Wilson 1999, p. 32). Especially since 1895, foreign companies rushed into Russia and within a few years a gigantic over-investment had taken place particularly in the Southern Russian steel and metal industry.

By 1899, the tide of the industrial boom in Russia had turned (Lyashchenko 1970, pp. 646-60). The Russian government announced the end of its massive infrastructure programmes, which created huge overcapacity in the heavy industries (Mosse 1996, pp. 119-20). The recession that would hit Europe one year later had a severe impact on Russia (Chlepner 1930, p. 83): the price of coal, iron ore, and steel halved between 1900 and 1903 (Peeters and Wilson 1999, p. 70), and railway construction nearly halved (Gatrell 1994, p. 48). This situation triggered a huge drop in the prices of Russian stocks. By mid-1901 the Russian stock prices had fallen to about 60 per cent of these at the beginning of 1900 (Chlepner 1930, p. 83). One third of the companies formed during the previous years were on the brink of bankruptcy (Peeters and Wilson 1999, p. 72). 
During the years 1900-6 (a period of depression, violent social conflicts, a revolution and a war with Japan) the average annual industrial growth rate barely tipped 1.4 per cent. The economic slump that began in 1899/1900 lasted much longer than expected. As a result, the Russian government decided in 1902 to countenance the formation of a syndicate in South Russia's iron and steel industry, financed by large French, German, Belgian and Russian banks (Gatrell 1994, p. 56; Crisp 1976, pp. 177-8; McKay 1970, pp. 281-2), which became known as Prodamet (Crisp 1976, p. 166, 175; Lyashchenko 1970, pp. 675-80; Lauwick 1907, p. 186). The manufacturers of locomotives negotiated the creation of a similar syndicate: Prodparovoz. Numerous other syndicates were formed (by 1914 there were about 150) (Falkus 1972, p. 78). By 1903, there was reason to believe that the worst of the economic crisis was over, but the Russian-Japanese war (8 February 1904 - 5 September 1905) would have serious consequences. With Russia defeated, large parts of the Russian army demoralised and the Russian financial situation being in dire straits, the years 1905-6 witnessed social and political instability. The 1905 Revolution prompted the transformation of the Tsarist autocracy into a constitutional monarchy with a parliamentary system ("October Manifesto"), although after several dissolutions of the Duma little remained of this. On the contrary, with the appointment of Pyotr Stolypin as Prime Minister a brutal regime, characterised by thousands of executions being ordered by special martial courts, was installed.

The economic situation in Russia improved in 1907, but industrial output dropped again the following year. Between 1907 and 1913, the average industrial growth rate in Russia rose to 6.3 per cent, with the period 1910-3 registering as much as 7.5 per cent (Crisp 1976, p. 111). However, the nature of the industrialisation process was different from that in the pre-1900 years. Whereas industrialisation during the 1890s was boosted by government spending in railway construction-which in 1900 still represented 25.7 per cent of national income- in the years 1908-13 spending on military armaments became the government's priority, accounting for 35.4 per cent of national income in 1913 and leading to the Russian steel industry's output expanding by 50 per cent between 1910 and 1913 (Trebilcock 1973, p. 270). Russia was much in demand by foreign investors wishing to develop 
the country's armament industries, especially in the period following Russia's 1905 defeat at the hands of Japan. Among the many foreign firms that responded positively were the French SchneiderCreusot and the British Vickers (Trebilcock 1973, p. 265). Similarly, the French Chantiers Navals, Ateliers et Fonderies de Nicolaïeff established shipbuilding operations at the Black Sea. During the period 1908-13, Russia spent an impressive 4,184 m rubles on armaments (Miller 1967, p. 132). While railway construction by the State had started again, it was on a much smaller scale than previously, as its role had diminished in the wake of the considerable increase in military-related expenditure (Gatrell 1982, pp. 99-110).

Russian industry started to eschew State control, with the role of the State being taken over by the deposit banks (Gerschenkron 1966, pp. 21-2). During the economic crisis years of 1900-3, the banks in Russia had experienced an important wave of concentration (Kahan 1989, p. 56). Moreover, as most foreign credit facilities were withdrawn, the new Russian investment banks were increasingly holding large proportions of industrial shares (Girault 1999, pp. 338, 569) and were showing a more direct interest in these companies' industrial activities. In addition, the State savings banks started playing a more prominent role in mobilising private savings. Until 1910, these savings banks' deposits were to a large extent invested in State funds, mortgages, and railway loans guaranteed by the government (Crisp 1976, pp. 125-32). Foreign banks, in turn, particularly French banks, were holding growing numbers of capital shares in Russian banks, such that by 1916 this foreign share component amounted to some 45 per cent (Crisp 1976, p. 147; Garvy 1972, p. 881; McKay 1970, pp. 234-7). Of this, 22 per cent was French (Crisp 1976, p. 172), strengthening the firm grip that the French banks had on many Russian industrial concerns (Girault 1999, pp. 472-514). The Franco-Belgian financial group "Syndicat des affaires russes" (founded in 1910 by Banque de l'Union Parisienne, Société Générale de Belgique, Thalmann et Cie and Hirsch et Cie) came to play a decisive role in the further industrialization of Russia (and building its military complex) on the eve of the First World War (Kuzmina 2015). 
During the 1880-1914 period, foreign investment played an important role in the industrialisation of Russia, whereas Russian capital was mainly active in the textile industry. This was also reflected at the BSE where many Russian stocks were listed and their market cap was very important: in 1914, the market capitalization for all Russian common stocks was 1.56 billion BEF (compared to a market cap of 4.09 billion BEF for common stocks of Belgian companies with main activity in Belgium). Of course, stocks of other nationalities were also listed on the BSE, but no single country was as popular as Russia, neither in terms of number of common stocks listed (table 1), nor in terms of market capitalisation: The market cap for stocks of all companies with main activity neither in Belgium, nor in Russia, was (in 1914) 7.42 billion BEF, with the market cap for some of the most important countries among them 1.25 billion BEF (France), 0.77 billion BEF (Germany) and 0.70 billion BEF (Spain).

\section{INSERT TABLE 1}

However, it remains most remarkable that the BSE was so highly focused on Russian common stocks. A combination of several elements can contribute to an explanation of the remarkable popularity of Russian stocks on the BSE. Apart from Russia's policy of attracting foreign investors, the government's massive railway construction programme, the industrialisation of South Russia and the monetary reforms, some other pull and push factors are associated with foreign investment in Russia. Firstly, there was the growing market potential in Russia. Between 1816 and 1914, the total population in Russia rose from around $45 \mathrm{~m}$ to $175 \mathrm{~m}$ and the growth of industrial production was impressive (Gerschenkron 1947). Russia was clearly shifting to a higher level of development as witnessed by the 1896 All-Russia industrial and art exhibition in Nizhny Novgorod, the establishment of Schools of Commerce (teaching book-keeping, commercial correspondence, law and intended to train leaders of Russian companies), the increasing importance of the St. Petersburg stock exchange (Borodkin 2009) and the ambitious railway program (Metzer 1974). Consequently, it was expected that Russia's economic growth would be at least comparable to that of the United States (Girault 
1999, p. 130). Secondly, this enthusiastic view seemed to be confirmed by the results of an important Belgian "first mover": Dniéprovienne, a daughter company of the Cockerill steel works which was among the first starters and paid out tremendously high dividends. Thirdly, foreign investment in Russia was, especially by France, considered to be of strategic importance in the country's 1894 military alliance with Russia against Germany vi. Enormous numbers of Russian State loans issued on the French market constituted the backbone of the Russian State ${ }^{\text {vii }}$, while many private French companies also invested in Russia (Girault 1999). It led to a real "Russia mania" in France where everything that was "Russian" would sold out to investors, who were not always aware of the social and political risks of their investment. As Belgian investors at the time were highly France-oriented (many mixed French-Belgian companies were incorporated) it is likely they shared this mania. The Belgian-French connections are also illustrated (as indicated before) by France being the second most important country for BSE investors (in terms of number of companies and market cap). In particular due to the fiscal measures during the 1890s in France (Hautcoeur 2007, p. 463) there was a migration of the enormous amount of Russian stocks emitted by French companies (Hautcoeur 2007, p. 469472) to the close by and French-speaking BSE, with one of the most free market legislations of Europe ("Une legislation belge très libérale") (Bitsch 1994, p.180) as well as an abundant capital market. Fourthly, the increased availability of capital in the international money market reduced interest rates elsewhere to extremely low levels (around 2 per cent) making it difficult for portfolio investors to live off their dividends. It made them increasingly looking abroad finding that the returns on foreign securities in Russia were higher (Kahan 1967, p. 475; Von Laue 1974, p. 105). Fifthly, despite the oppressive Tsarist regime, Russia seemed to be a reliable country as it had always paid its interests due, in contrast to countries such as the Ottoman Empire or Argentina. Sixthly, Russia was confronted with an inflow of foreign companies that invested mainly to exploit their technological advantages (such as tramways or steel) and that eagerly looked forward to expanding foreign markets. Evidently, these companies (and the banks that were supporting them) attempted to tap the Belgian financial market by attracting portfolio investors. Listing stocks on the BSE was initiated 
by all of these companies expanding towards Russia by means of daughter companies. Seventhly, in order to convince portfolio investors, there was a real marketing campaign organised by the press even partly paid by the Russians themselves (the Raffalovitch scandalviii). For example, in 1895 a series of articles was published in the "Economiste Internationale" (9 February, 18 May, 25 May, 1 June, 8 June, 22 June) promoting investing in Russia. Especially the French press promoted such investments (these journals had a big influence in Belgium too), but also Belgian newspapers such as the "Moniteur des Intérêts Matériels"ix followed suit. Besides, the banks, especially the Crédit Lyonnais (Bonin 2010), promoted these investments, as did even the stock exchange authorities (Girault 1999, p. 130). Eightly, the portfolio investment environment of the late 1890s, which was highly international and rather modern, should not be underestimated. Portfolio investors were well aware of the benefits of diversification and were not afraid of investing in stocks all over the world. Experts - as for example Alfred Neymarck, the founder in 1869 of the economic and financial journal "Le Rentier" and the co-organiser of the famous international congress of 1900 (the "Congrès des valeurs mobilières") - stimulated such international investment. Paul Leroy-Beaulieu too had an enormous influence on the behaviour of French-speaking investors. His 1905 book "L'art de placer et gérer sa fortune" (summarizing the articles published for years in the "Economiste Français" in a special section called "Conseils généraux pour le placement d'une fortune") was printed over and over again (Leroy-Beaulieu 1905). Last but not least, it seems timing was important: most companies were listed during the booming years 1895-1899. It was especially that short period that attracted many companies to the Russian market - a typical phenomenon of "stock mania fever", implying that whenever a new industry or country promises to reap high (future) returns, investors jump in massively. This was certainly the case for Russia. It implied that many firms were undercapitalized; there were also several firms that had even not started up production when the crisis broke out in 1899. Heavy disappointment was the result, as evidenced for example by Belgian parliamentary debates early 1902: during this extensive session, parliamentary opposition attacked the government for not having any investor-protecting legislation against those selling stocks by any means to 
ignorant investors, as well as for not having warned against the excessive bull market of the late 1890s (Belgian Chamber of Representatives, 28 January 1902).

Data on foreign capital in Russia are summarized in McKay $(1970$, p. 32, 34) and mainly based on Pavel Ol' (Ol' 1983). Whereas the amount of total foreign capital in Russian industry doubled in the 1880 s, it more than quadrupled in the 1890s. Furthermore, in 1915 , this total was 2.5 times that of $1900^{x}:$ In 1880 the total amount of foreign capital in all corporations was $91.5 \mathrm{~m}$ rubles; it amounted to $761.9 \mathrm{~m}$ rubles in 1900 and to $1,939.3 \mathrm{~m}$ rubles in $1915^{\mathrm{xi}}$. By nationality France and Belgian investments initially took the lead: In 1900, France represented 210.1 m rubles (or 27.5 per cent of total foreign capital), against $220.1 \mathrm{~m}$ rubles (or 28.9 per cent) for Belgium. These figures provide sufficient evidence of the spectacular growth in foreign investment in the empire, although the "nationality" of capital was not always that clear (McKay 1970, p. 36; Verstraete, 1900; Claeys, 2015). Taking into account the crisis and recession years of 1900-7, the growth of this investment over the subsequent eight years is also remarkable, but the relative shares of the countries of origin changed: in 1915, France represented 30.7 per cent (594.4 m rubles), followed by Great Britain with 25.3 per cent (491.5 m rubles), Germany with 20.6 per cent (399 m rubles) and Belgium with 11.9 per cent (230.4 $\mathrm{m}$ rubles).

We study portfolio investments in shares of companies investing in Russia and listed on the BSE. These stocks (both Belgian and non-Belgian) were the most important compartment at the BSE before 1914. But this sample of Russian stocks represents only a small, although important segment of the Russian economy: it only takes into account the stocks listed on a foreign exchange, whereas not every foreign company investing in Russia was listed and rarely were the pure Russian companies listed outside Russia. Moreover, the sample is biased: most of these companies were geographically concentrated in Southern Russia and within a specific number of industries such as mining, metal, steel and transportation. Numerous Russian companies at the time were mainly in textiles and much 
more located around the Moscow and St. Petersburg regions. Our sample essentially represents mainly the companies in the (initially) more backward region of Southern Russia (but within a few decades transformed into the industrial heart of Russia).

The active participation of Belgian companies in the Russia investment rally prompted scholars such as Chlepner to talk of a "croisade des capitaux belges en Russie" (Chlepner 1930, p. 82) and Stols to describe South Russia as a "province industrielle belge" (Stols 1987, p. 81). Nevertheless, a warning is in place: on the BSE, numerous companies investing in Russia were listed, but they were not always purely Belgian companies. The majority of companies in our sample are either French-Belgian, Belgian or French companies, besides others. In fact, companies listed on the BSE at the time were often of a very cosmopolitan nature as their capital came (besides from Belgians) from many different other sources, mainly French but also German, British, and even American and Russian (Bitsch 1994, pp. 184-214; Girault 1999, p. 64, pp. 260-1). Indeed, some Russian companies also rushed towards the BSE (or to other exchanges, especially the Paris Stock Exchange) to get additional capital (Borodkin 2009). Belgium at the time was an extremely attractive financial centre with a very business-oriented legislative framework and tax system (practically no taxes had to be paid) (Bitsch 1994, p. 180). Consequently, many companies had stocks listed in Brussels. Of course, many of the companies founded by Belgian companies had a natural home-biased incentive to list on the BSE. The first company investing in Russia ever to be listed on the BSE was the railroad company, Chemin de Fer de Varsovie à Vienne (established in 1857; listed in 1860). In the next two decades, several tramway and railroad companies would follow suit. However, it was only from the 1890 s onwards that numerous companies investing in Russia began to be listed on the BSE. Within this group, an important position was taken by Belgian companies. One of the outstanding examples of Belgian investment was the Belgian Métallurgique Dniéprovienne du Midi de la Russie, (a daughter company of Cockerill founded in 1886) (Dumoulin 1987, p. 58). Dniéprovienne was one of the most profitable firms in Russia. For an initial, nominal share price of 500 rubles $^{\text {xii }}$, investors received dividends of 50 rubles in the 1889-90 financial year, which rose steadily to 200 rubles in the $1897 / 8$ financial year 
alone. Stock market prices rose from 1,540 francs on IPO day ${ }^{\text {xiii }}$ (12 June 1891) to 9,076 francs (30 November 1898). Investors, though, had the expectation that this would be a never-ending success story, and jumped in. Dniéprovienne was a first mover, encouraging other Belgian companies in the coal, steel, and metal industries to follow its example. Within a few years a real rush of foreign companies took place, joining the first mover and creating over-investment while participating in this mania, a phenomenon that has time and again been observed in history (railway mania, ICT-mania). Investments outside the coal, steel, and metal industries should not be overlooked. The number of newly-incorporated firms aiming to invest in Russia rose steadily in sectors such as glass, urban transport, shipbuilding, and electricity. The range of investments made by BSE-listed companies in Russia was broad, even in new sectors, such as oil (Nizet 1987) and chemicals.

The surge in foreign investment coming into Russia came to an abrupt halt in 1899. Many of the BSElisted companies disappeared or were taken over by other entities. But others were able to stay afloat. Even new ones were established. In the period 1909-14, some 72 per cent of all investments in the tramway sector in Russia came from BSE-listed companies, controlling about half the tramway companies of Russia (Coopersmith 1992, p. 76). By 1908, the industrial overproduction of the previous years had been absorbed and foreign investment resumed, despite a hostile nationalist and anti-foreigner sentiment, which was often directed at foreign-owned tramway companies (Owen 1991, p. 171).

IV

To measure investment performance we will use the total return earned on the listed shares. Total returns reflect both capital gains (or losses) and dividend income. In contrast, some performance measurements rely on accounting data, which often do not reflect reality due to the absence of wellestablished accounting rules, the presence of inflation or the sometimes arbitrary depreciation policies of the reporting companies. To compute total returns, we apply standard methodology (Dimson, Marsh, and Staunton 2002), which is based on stock market prices and dividends. The main restriction of this approach, however, is that only the performance of quoted stocks can be 
measured, and that it therefore misses out the many unquoted ones. In measuring total returns, it is important to take into account all capital operations such as stock splits, mergers, right issues etc. As investors are interested in real performance, i.e. after considering loss of purchasing power due to inflation, we will deflate nominal returns by using estimates of Belgian inflation. Consistent with the literature we calculate both geometric and arithmetic averages. The geometric average reflects the average growth rate of invested capital, assuming all income is reinvested when received. As such it is a good measure of ex-post performance as experienced by investors. The arithmetic average, on the other hand, provides an unbiased estimate of ex-ante expected returns, assuming that the sample used is representative of potential future outcomes. However, it should be noted that the volatile nature of asset returns makes this a very inaccurate and therefore blunt instrument to measure expected returns. Mathematically, the arithmetic average will always be higher than the geometric average, except in the non-realistic case of constant returns. The difference between both is larger for more volatile investments.

The data used are from the (University of Antwerp-based) SCOB database which, for all quoted stocks and bonds, contains end-of-month prices, dividend and interest payments, numbers of shares and bonds, and ex-dividend day. The database was constructed from the official quotation lists of the BSE and checked in secondary sources, primarily the Recueil Financier. ${ }^{\text {xiv }}$ The database consists of individual prices of BSE stocks starting with only two stocks in 1832 and growing steadily up until 1914 (Annaert, Buelens and De Ceuster 2012). In this study, we consider the 1880-1914 data, leaving out those for $1860-80$ as the latter period covers only the history of the stocks of only one Russian BSE-listed company.

Based on the official price lists of the BSE, data on dividends are also available from 1873 onwards, including information on the type of dividend, the day of payment and the currency (dividends of foreign-based companies were often paid in foreign currencies) and the successive coupon numbers. Laspeyres' market capitalisation weighted price return indices were calculated on a monthly basis. The return index reflects the value of an investment of 100 Belgian francs in, for example, Russian 
stocks at the beginning of the period, reinvesting all dividend income in all stocks available. In contrast, the price index does not contain dividends and is a more accurate reflection of the business cycle as it is generally assumed to incorporate expectations about future profits. Stock prices capture the hopes and fears of investors at any time and their estimation of all future returns on their investment $^{\mathrm{xv}}$.

If $I_{t}$ denotes the value of the index at the end of period $t$, the indices are constructed as follows:

$$
I_{t}=I_{t-1} \cdot\left(1+\sum_{i=1}^{L_{t-1}} w_{i t-1} r_{i t}\right)
$$

where $w_{i t-1}$ is the weight attached to stock $i, L_{t-1}$ is the number of stocks at the end of period (month) $t-1$ and $r_{i t}$ is the simple return of stock $i$, including (excluding) dividends for the total return (price) indices. At the beginning of each subperiod studied, $l$ is set as equal to 100 . Weights are relative market capitalisations:

$$
w_{j t-1}=\frac{P_{j t-1} N_{j t-1}}{\sum_{j=1}^{L_{t-1}} P_{j t-1} N_{j t-1}}
$$

where $P_{j t-1}$ is the price for stock $j$ at $t-1$ and $N_{j t-1}$ is the number of shares for stock $j$ at $t-1$.

Some further remarks about the methodology are warranted. First of all, total return is calculated under the assumption that investors reinvest dividends on ex-dividend day. Second, indices for all samples are calculated including all shares listed at any point in time in order to avoid selection bias in the data. Building a return index containing only the stocks that survived until the end of our sample period would bias the calculated average returns upwards and the calculated risk downwards, as the firms that failed are excluded from the analysis. Of course, contemporaneous investors would not have been so lucky. Third, returns are weighted by market capitalisation so as to reflect the perspective of the average investor and to avoid distortion due to smaller, relatively insignificant companies. Fourth, we adjust for various capital operations, such as stock splits, bonus shares, reverse splits, attribution and inscription rights. Fifth, our return calculations are not heavily impacted by delistings. As indicated, we include all stocks until they delist. The delisting return often 
lacks, but it is not material to our results as the price of securities to be delisted falls towards zero in the months before delisting. As such their impact on return indices that are market capitalisation weighted is negligible. ${ }^{\text {vi }}$ Finally, in order to take inflation into account, deflated time series for returns are used. The Belgian consumer price index (CPI) is used to deflate the nominal series. For the period before World War I, we use data from Michotte (1937, pp. 346-57) and Van De Velde (1943, pp. 21-5).

We calculate BSE stock price data for Russian stocks for the period 1880-1914 (134 companies with stocks) and compare with data on Belgian stocks listed on the BSE for the same period (650 Belgian companies). These data allow more precise identification of important moments.

In 1880, only one Russian stock was listed: Chemin de Fer de Varsovie à Vienne, listed on 20 April 1860, and the only stock listed until 1881. Other companies investing in Russia would follow, but only with bonds, as for example Crédit Foncier Mutuel de Russie (listed in 1870). In 1881, two additional companies were listed, but only one with stocks: Tramways d'Odessa. From 1881 until 1889, the number of new listings of Russian stocks was small.

From 1889 onwards, the number of listings increased gradually. In 1889, three new companies had stocks listed: Chemins de Fer du Sud Ouest de Russie, Chemin de Fer de la Baltique, and Chemins de Fer de Fastowo. In the same year, Compagnie générale de Tramways de Moscou et de Russie and Tramways de Rostoff-sur-le-Don were listed. Importantly, until 1891 only the transportation sector (tramways and railroads) was listed and railroad companies represented most of the market capitalisation. 1891 witnessed the IPO of two companies in the steel and metal business, Usines de Briansk and Société Métallurgique Dniéprovienne du Midi de la Russie. Although both companies had already been in existence for some time (Usines de Briansk since 1873, Dniéprovienne since 1886), it was only in 1891 that they turned to the BSE. In addition, another railroad company was introduced in 1891, Chemins de Fer de Koursk Charkoff.

The real expansionist wave came during the mid-1890s. This is clearly illustrated in Figure 1 which 
shows all new IPOs of companies (stocks only), all delistings ${ }^{\text {xvii }}$ and the total number of still-listed Russian BSE companies. The 1890s were really outstanding with a total of 78 new listings out of 134 for the whole sample. After 1895, the number of new IPOs multiplied within a few years ${ }^{\text {xviii. }}$. Already by 1895 (common stocks only) the number of listings was 15, while in 1896 an additional 15 companies were listed with stocks. The top years were 1898 (with 21 new listings) and 1899 (with 18 new listings). Consequently, for the first time, the index represented a fairly diversified sample of industries (transportation, coal, metal, steel, and mining) instead of being simply a transportation index.

\section{INSERT FIGURE 1}

Almost no delistings took place at the time and the total number of companies listed increased (delistings subtracted), with the total number of companies listing in 1898 standing at 63 . The rush was not over, however, as in 1899 as many as 80 companies were listed. As that time several companies that went bankrupt later on had not even started production; others were highly undercapitalized. Initially, the crisis of $1899 / 1900$ did not stop the increase in listings as 86 companies were listed in 1900 and 89 companies in 1901. The real turning point came in 1902 when the number dropped to 77 companies, in 1903 to 73 companies, and in 1904 when it dropped still further to 72 companies. Remarkably, the number rose again to 79 in 1911 and 1912 and to 81 in 1913 and 1914. During the entire period under consideration, 53 companies had been delisted out of a total of 134 companies with stocks.

The IPO listing history is important for understanding the composition of the Russian BSE index as compared to the Belgian all share index (Figure 2). Our indices start in 1890 (31 December $1889=$ 100). A comparison for the period $1880-90$ is of limited use: Until 1890, the Russian index is, as indicated, an index of transportation companies with a small number of stocks, while the Belgian index is an all share index, widely diversified across industries. From 1891 onwards, and especially 
from the mid-1890s when the number of Russian stocks was rising rapidly, both indices represent an all share index with a diversified range of industries and a substantial number of companies.

\section{INSERT FIGURE 2}

Four striking observations can be made. First, the two price indices seem to follow the same path until 1899/1900. Second, both indices evidence a huge drop in 1899/1900, although the Russian price index already starts to plummet nearly one year earlier (in mid-1899) whereas for the Belgian price index this occurs only in early 1900 . This clearly corresponds with the major economic crisis of 1899-1902 which gripped many countries but did not evolve entirely synchronously: The crisis clearly manifested itself earlier in Russia than in Belgium (Thorp 1926; Lauwick 1907, p. 139). Third, another important difference can be found in the first decade of the twentieth century, with the Russian price index adopting a different path from 1902/3 onwards, which was to endure for years to come. Whereas the Belgian price index had already recovered from the crisis by July 1902 , the Russian stock price index drops further from 127.70 in May 1899 (index value 100 on 31 December 1889) to below 42.26 in June 1907. The socio-political events of 1904-1906/7 were highly responsible to this. A number of unforeseeable events, war and revolution, took place, as described in section one. Owing to the long duration and severity of the Russian price drop, the index was comparable to the big stock market slump in the 1930s. The Russian stock price index only really started to recover in 1909 when it doubled from 42.31 in March 1909 to 85.07 in September 1912. Fourth, the recovery seen in the Russian index in the last decade was very strong-in fact, much stronger than it was for the Belgian index. During the period 1910-4, the Belgian price index showed capital losses of 11 per cent, in contrast to capital gains of 42 per cent for the Russian price index. This recovery was, as indicated in section one, mainly due to the massive rearmament program of the Tsar and the index reflecting by now the survivors only. 
The evolution of prices over time captures only capital gains or losses. Total return-adding dividend yields to the capital gains (or losses) - is what really matters. From the evolution of the price index it is clear that the time period 1880-1914 should be split in three sub-periods: 1880 until 1900, 1900 until 1907-9, and 1909 until 1914. First, total returns over the decades (1880-9, 1890-9, 1900-9, $1910-4)^{\mathrm{xix}}$ are considered. Thereafter, total returns for particularly important sub-periods are calculated, such as the boom of 1895-9 and the depression of 1900-7. Finally, returns are calculated for the whole period (1880-1914, 1890-1914). As before, all Russian stocks in the sample are considered and compared with all stocks of Belgian companies mainly investing in Belgium. Table 2 shows data on total nominal and real return (geometric average, arithmetic average), standard deviation, dividend yield and Sharpe ratios ${ }^{\mathrm{xx}}$ of Russian and Belgian stocks on the BSE. First of all, some observations regarding inflation are pertinent. For example, during 1890-1914 nominal Russian returns were 2.06 per cent whereas real returns were 1.17 per cent-depending, though, on the inflation data used. As inflation data for the period before 1914 are not of the same quality as that after the First World War, all recalculated real data should be viewed with caution. Yet inflation did not seem to be a problem (the difference between nominal and real returns was much greater after the War). Second, volatility in Russian stocks (as measured by the standard deviation) was not high, and was even below or comparable with long-term historical averages for the world ${ }^{x \times i}$. Third, it appears that the average dividend yield for Russian stocks was within the range of international normally observed yields (on average, around 4 per cent over longer time periods).

INSERT TABLE 2

Turning next to the returns per decade, the total real (geometric) return for Russian stocks was around 6.33 per cent for $1890-9$ which is higher than typical long-run returns on equity investments ${ }^{\mathrm{xxi}}$. However, caution is required when interpreting the data for $1880-9$ (total return of 10.06 per cent) which relate to a limited number of companies operating only within the transportation industry. Compared with the Belgian all share data, the Russian stocks were not 
behaving in too dissimilar a manner. In fact, returns for the period 1890-9 were somewhat higher for Belgian stocks (6.62 per cent). The returns on Russian and Belgian stocks deviated markedly over the next two decades. During the period 1900-9, Russian returns collapsed to minus 6.64 per cent, while Belgian returns stood at 5.19 per cent. Moreover, looking at the returns of $1900-7$, the severity of the crisis appears even more pronounced, with Russian negative total returns having dropped to minus 9.56 per cent-in stark contrast to Belgian returns of 3.79 per cent. During the subsequent 1910-4 period, the picture changed, with returns on Russian stocks standing at 7.54 per cent and returns on Belgian stocks at minus 1.83 per cent. The huge losses on Russian stocks during the period 1900-9 had important consequences for the country's total returns over the whole period under consideration: for 1880-1914 they were 3.63 per cent and for 1890-1914 only 1.17 per cent. In contrast, returns on Belgian stocks were 4.63 per cent and 4.31 per cent, respectively. Clearly, the negative results in the period $1900-7$ had a major role to play in Russia's extremely low total returns over the entire period. To put these exceptionally negative results into historical perspective, Belgium only saw such severely negative results twice during the whole of the twentieth century: during 1910-9 (minus 7.59 per cent) and during the economic crisis of the 1930s (minus 6.61 per cent in 1929-39). The overall total returns for the whole period (1880-1914 or 1890-1914) were lower for investments in Russia than they were for a highly-developed and industrialised country like Belgium. In the case of investments in Russian stocks, low returns were the result of unexpected events. Socio-political events exacerbated the effect of the crisis of 1900-2, and were responsible for the negative annual returns of 1900-7. In addition, the strong revival seen in 1910-4 was interrupted by two major events: the First World War and the 1917 revolution in Russia.

However, this conclusion is only part of the story, as will be discussed in the next section. The issue directly derives from the Sharpe ratios in table 2. As explained in more detail in section VII, the Sharpe ratio captures the risk-return trade-off and is calculated by dividing the average excess return by its standard deviation. Table 2 indicates that the Sharpe ratio for Belgian stocks was not always higher in all sub-periods. But computed over longer periods (1880-1914; 1890-1914) Sharpe ratios 
(on an annual basis) are between 0.12 and 0.33 for Belgium and between -0.01 and 0.13 for Russia.

To explain why investors were diversifying into Russian stocks despite their lower average return and higher risk we study the correlation between Russian and Belgian stocks. Low correlation would provide an incentive for diversification (Le Bris 2013). Such diversification could bring about a decrease in the overall level of portfolio risk, and a better risk-return trade-off (section VII).

VII

From the discussion in section VI it is clear that BSE portfolio investors did not always earn higher returns from their Russian equity investment than from a purely domestic equity investment. This does not mean that their choice to buy Russian shares was wrong. First, equity returns are notoriously volatile, as can also be seen from the standard deviations reported in table 2 . Return outcomes deviating considerably from what was expected are therefore probable. In this view, the worse performance of Russian shares was due to "bad luck". Secondly, achieving higher returns is not the sole motivation to invest in foreign stocks. When confronted with uncertain return prospects, investors may want to diversify their portfolios to reduce risk. Diversification works well when the different investment prospects are not perfectly correlated. Again table 2 shows that Belgian and Russian stocks do not move in lockstep: there are periods when Russian stocks perform better than Belgian stocks and vice versa. Although Markowitz (1952), the father of Modern Portfolio Theory (MPT), was the first to formalize mathematically this idea of risk reduction by diversification, the notion was well-known among nineteenth century investors. ${ }^{\text {xiii }}$ Following Goetzmann and Ukhov (2006) and Edlinger, Merli and Parent (2013), we use MPT to investigate to what extent the popularity of Russian shares on the BSE was driven by investors wishing to diversify their domestic portfolios. According to MPT, investors maximize a utility function that depends positively on the expected return of their portfolio and negatively on portfolio risk. Risk is measured by the standard deviation of portfolio returns, also called volatility. Markowitz (1952) suggested a two-step procedure as follows. First, determine for each level of risk the portfolio that maximizes its expected return. When plotted this leads to a so-called efficient frontier, i.e. a set of 
potentially optimal or efficient portfolios. This is illustrated in figure 3. The expected portfolio return is read on the vertical axis, whereas the horizontal axis measures portfolio return volatility. The thick concave line A-TP-B depicts the efficient frontier. All risky assets would plot on this curve or below. Clearly, the investor would not be interested in investing all his/her money in an asset plotting below the efficient frontier. Only the efficient portfolios are candidate portfolios. In a second step, the investor chooses among the efficient portfolios the portfolio that maximizes his/her utility function. The optimal solution therefore depends on the investor's risk aversion: there are as many optimal portfolios as there are investors. However, Tobin (1958) shows that whenever investors can also invest in a riskless asset, any investor's optimal portfolio is a combination of the riskless asset and a portfolio that contains only risky assets. This risky portfolio is called the tangency portfolio (TP), as it is the efficient portfolio that lies on the tangent line, drawn from the riskless rate of return, to the efficient frontier. This is also illustrated in figure 3, where the TP is plotted on the intersection of the efficient frontier and the Capital Allocation Line (CAL), the straight line starting at the level of the riskless rate of return $r_{f}$. Every investor invests in the TP and in the riskless asset, but the investment proportions depend on their risk aversion. As such the TP can be interpreted as the unique optimal portfolio containing only risky assets. By definition, the TP is the portfolio that maximizes its rewardto-volatility ratio also known as Sharpe ratio (Sharpe 1994), which is given for any portfolio $p$ by

$$
S_{p}=\frac{E\left(r_{p}\right)-r_{f}}{\sigma_{p}}
$$

where $\sigma_{p}$ is the standard deviation of returns for portfolio $p$ and $r_{f}$ the riskless rate of return. The Sharpe ratio is thus the slope of the CAL. As can be seen, the optimal risky portfolio TP has a high expected return, a low volatility, or a combination of two. It also follows that its portfolio weights depend on estimates of the expected return of each asset, their standard deviations and the correlation coefficients between each pair of asset returns.

\section{INSERT FIGURE 3}

Indeed, to obtain a portfolio with a low volatility, the correlation pattern between the potential 
investment opportunities can be exploited. To see this, consider the case where there are only two risky assets, which is also the case we will study empirically. The return variance $\sigma_{p}^{2}$ for any portfolio that invests a proportion $w_{1}$ in risky asset 1 and a proportion $w_{2}=1-w_{1}$ in risky asset 2 can be written as follows:

$$
\sigma_{p}^{2}=w_{1}^{2} \sigma_{1}^{2}+w_{2}^{2} \sigma_{2}^{2}+2 w_{1} w_{2} \rho \sigma_{1} \sigma_{2}
$$

where $\rho$ is the correlation between the returns of both assets. It follows that the lower this correlation is, the lower the risk of the resulting portfolio becomes. Hence, it may make perfect sense to include a risky asset with a low expected return and/or a high return volatility in the TP as long as its return has a low correlation with the other asset(s) in the portfolio.

To investigate whether the desire to build low risk portfolios spurred the interest of investors for Russian shares listed on the BSE, we estimate the composition of the TP, assuming an investor can invest only in Belgian and Russian shares as well as the riskless asset. ${ }^{\text {xxiv }}$ Of course, we do not know the returns they anticipated nor their risk estimates. We therefore estimate these parameters using realized returns. More specifically, we use the arithmetic average return to proxy for expected returns. Averages are computed for Belgian and Russian stock investments using monthly return data from January 1880 to July 1914 . Returns are computed in excess of a riskless investment. ${ }^{x \times v}$ Likewise, volatilities and correlations are estimated by their sample counterparts. The annualised results are in table 3. We find that the correlation between both return series over the entire period is 0.30 , considerably lower than one. ${ }^{x x v i}$ This value is even somewhat lower than the 0.39 Goetzmann and Ukhov (2006) document for the correlation between UK and overseas equity over the period 18701913 and which allows UK investors to diversify their investment risk by adding overseas equity to their domestic portfolio. This suggests that Russian equity investments would be able to reduce the risk of purely Belgian equity portfolios considerably. We will now study whether this advantage is sufficient to compensate the lower average return of Russian shares. 


\section{INSERT TABLE 3}

When we compute the TP, we find that Russian stocks account for $4.5 \%$ of the optimal risky portfolio for Belgian investors. This results in an only marginally higher Sharpe ratio compared to the Sharpe ratio of a portfolio investing only in Belgian equity, casting doubt on the diversification offered by Russian shares. But before we discard Russian equity as a useful diversification tool, we have to take into account at least two caveats. First, the results are derived using ex-post estimates of expected returns and it is well-known that the TP is extremely sensitive to return inputs (Best and Grauer 1991). We have seen above that average return was particularly low for Russian equity in the period studied. Undoubtedly, investors expected to earn more ex-ante, which would have increased the optimal proportion of Russian equity in the risky portfolio. Secondly, given the economic evolution and the changing industry composition of the Russian sample, it is likely that input parameters for portfolio optimisation are also time-varying. We investigate both issues.

To account for the uncertain nature of expected returns, we follow Goetzmann and Ukhov (2006) and assume that investors expected Russian equity to perform as well as Belgian equity ${ }^{\text {xxvii }}$. When expected returns are identical across all eligible risky assets, all portfolios will have the same expected return and the investor can only attempt to reduce its risk. The optimal risky portfolio is therefore the minimum variance portfolio (MVP). ${ }^{x v i i i}$ This implies that we do not need to make any assumption regarding the anticipated expected returns, which makes this portfolio much more robust than the ex-post TP. We see in table 3 that the proportion invested in Russian equity nearly doubles to about $8 \%$, with hardly any effect on the ex-post Sharpe ratio. But it seems unlikely that this result can explain the popularity of Russian equity on the BSE.

Alternatively, diversification opportunities may have been time-varying. To test this possibility, we compute correlation coefficients over rolling samples of 120 months (ten years) ${ }^{x x i x}$. The results are shown in figure 4. Its time axis indicates the month at which the ten-year correlation could have been computed by contemporaneous investors. We indeed find that correlation is very volatile. Until about 1895 it hoovers around 0.10 after which it gradually increases to about 0.30 in 1900 . Over the 
course of the next year it doubles to approximately 0.60 . It then remains between $0.50-0.60$ for the next decade. From 1910 onwards the correlation drops again, but stays well above 0.3 during the last years of our sample.

\section{INSERT FIGURE 4}

Needless to say, these patterns have a clear impact on the proportion of Russian shares in the MVP, which is also shown in figure 4. Between 1890 and 1900, the MVP contains between $10 \%$ and $30 \%$ of Russian stocks. The proportion then spectacularly drops off towards zero in 1901. Afterwards, it increases again, but stays generally far below $10 \%$ for the remaining part of the sample. It seems that in order to explain the popularity of Russian equity on the BSE during the period studied, we could argue that initially investors were lured by good diversification possibilities. If we add to this observation the fact that the limited sample of Russian stocks had performed extremely well before 1890 (a period we did not take into account when computing the optimal portfolio in the rolling samples), it is no surprise that Russian investments enjoyed the interest of Belgian investors. Whether they were as enthusiastic after experiencing their lacklustre performance after 1899 is equally doubtful and may help explain why the number of Russian shares listed on the BSE drops off around 1902, as described in Section V.

VIII

From 1895 until 1914, Russia was the most important (foreign) segment of the BSE. The profit motive was certainly there: Russia as a potential Eldorado was a view shared by many. Besides high ex-ante promised returns, the initially low correlation between Russian and Belgian stock returns provided also ample diversification opportunities. Throughout the period studied total returns were first rather high, then dropped tremendously and then rose again. But in the end - take the whole period into account - the ex-post total returns of all Russian BSE stocks were low (lower than in Belgian stock returns), although the most important industry (steel) realized higher ex post returns, notwithstanding the overall picture. 
This indicates that investing in Russian shares listed on the BSE was not the best investment decision in the end. But this is an ex-post conclusion. Ex-ante expectations may have been different, yet using MPT it is hard to rationalize the popularity Russian shares enjoyed in Belgium. This is perhaps not surprising as the main reason for the gap between ex-ante and ex-post is not to be found in the economics. It lies within the social, political, and military turmoil of the early 1900s: the sociopolitical events of the first decades of the 1900s have dominated the period of investment. It seems that foreigners were prepared to invest in an environment that was much riskier than they believed at first. They underestimated the socio-political events that were up to come due to a backward authoritarian Tsarist Russia (with violent repression and refusing social and democratic rights). For example, Marcel Lauwick (Lauwick 1907), a lawyer at the Brussels Bar, made a long journey through Russia at the behest of the Belgian government and declared in his 1907 report that prospects were bright and that all news about the 1905 revolutionary year was exaggerated. He even applauded the massive executions by the Tsarist martial courts. Of course, not everyone shared this view and pessimistic positions are also observed (Yurick 1959, p. 165, 179). But in the end investors preferred to believe in a bright future.

Unfortunately, investors not only underestimated socio-political conditions within Russia but also the geo-political situation with all its implications of rivalries between (and ambitions of) the big powers at the time. With the First World War and the 1917 revolution (and its aftermath) bringing an ultimate end to all hopes, the investment horizon was abruptly cut short. Thus the Russian case with its limited investment horizon is a perfect illustration that promised high (ex ante) returns will not necessarily be realized with higher (ex-post) returns. As the Russian case demonstrates neglecting or misunderstanding socio-political conditions and the geo-political situation can have devastating results.

\section{REFERENCES}

ANNAERT, J., BUELENS, F. and M.DE CEUSTER (2012). New Belgian stock market returns, 1832-1914 
Explorations in Economic History 49, 189-204

BAIROCH, P. (1982). International industrialisation levels from 1750 to 1980. The Journal of European Economic History 11, 269-312.

BAYKOV, A. (1954). The economic development of Russia. Economic History Review 7, 137-49.

BELGIUM, Belgian Chamber of Representatives, 28 January 1902 (online available at:

https://sites.google.com/site/bplenum/proceedings/1902).

BEST, M. J., and GRAUER, R. R. (1991). On the sensitivity of mean-variance-efficient portfolios to changes in asset means. Some analytical and computational results. Review of Financial Studies 4, $315-42$.

BITSCH, M.T. (1994). La Belgique entre la France et l'Allemagne: 1905-1914. Paris: Publications de la Sorbonne.

BLANCHARD, I. (2000). Russian railway construction and the Urals charcoal, iron and steel industry 1851-1914. Economic History Review 53, 107-26.

BODIE, Z., KANE, A. and MARCUS, A. J. (2014). Investments. Maidenhead, Berkshire : McGraw-Hill. BONIN, H. (2010). L'épargne française exposée aux risques russes dans les années 1900-1920: la réalité d'actifs tangibles et mobils. Les Cahiers Irice 2(6), 19-34.

BORODKIN, L. I. and KONOVALOVA, A. (2009). Les moyens de financement des entreprises métallurgiques aux débuts de l'industrialisation russe (1880-1914): Le rôle du marché boursier. In L. Quennouelle-Corre and A. Straus (eds.), Financer les entreprises face aux mutations économiques du XXe siècle. Paris: Comité pour l'histoire économique et financière de la France, 11-40.

BORODKIN, L. I. and PERELMAN, G. (2011). St. Petersburg exchange: on the road to maturity. Industrial stock index, 1897-1914. In Y. Cassis and L. Quennouelle-Corre (eds.), Financial centres and international capital flows in the nineteenth and twentieth centuries. Oxford: Oxford University Press, 96-125.

BOVYKIN, V.I. (1990). Les emprunts extérieurs russes. Revue d'économie financière 14, 81-92. BRUSSELS STOCK EXCHANGE (1880-1914). Cours authentique de la bourse de Bruxelles. Brussels: 
Brussels Stock Exchange.

CARSTENSEN, F.V. (1977). Numbers and reality: a critique of foreign investment estimates in Tsarist Russia. In M. Levy-Leboyer (ed.), La position internationale de la France: Aspects économiques et financiers XIXe-XXe siècles. Paris: Editions de E.H.E.S.S., 275-83.

CARSTENSEN, F.V. (1983). Foreign participation in Russian economic life: Notes on British enterprise, 1865-1914. In G. Guroff and F.V. Carstensen (eds.), Entrepreneurship in imperial Russia and the Soviet Union. Princeton, NJ: Princeton University Press, 140-58.

CATIN, R. (1927). Le portefeuille étranger de la France entre 1870 et 1914. Paris: Faculté de droit de I’Université de Paris.

CHAMBERS, D. (2010). Going public in interwar Britain. Financial History Review 17, 51-71.

CHAMBERS, D. and ESTEVES, R. (2014). The first global emerging markets investor: Foreign \& Colonial Investment Trust 1880-1913. Explorations in Economic History 52, 1-21.

CHLEPNER, B.S. (1930). Le marché financier belge depuis cent ans. Brussels: Librairies Falk.

CLAEYS, T. (2015), Les Investissements Français en Russie de 1857 à 1914: Conseils, expertises et strategies. Quaestio Rossica 4, 163-79

COOPERSMITH, J. (1992). The electrification of Russia, 1880-1926. Ithaca, N.Y: Cornell University Press.

CRISP, O. (1976). Studies in the Russian economy before 1914. London and Basingstoke: The Macmillan Press Ltd./Barnes \& Noble.

DIMSON, E., MARSH, P., and STAUNTON, M. (2002). Triumph of the optimists: 101 years of global investment returns. Princeton, NJ: Princeton University Press.

DIMSON, E., MARSH, P., and STAUNTON, M. (2015). Crédit Suisse global investment returns sourcebook 2015. Zurich: Crédit Suisse.

DUMOULIN, M. (1987). Aspecten van de Belgisch-Russische economische relaties tijdens de belle époque. In E. Stols and E. Waegemans (eds.), Montagne russe. Belevenissen van Belgen in Rusland. Berchem: EPO, 57-69. 
EDELSTEIN, M. (1976). Realized rates of return on UK home and overseas portfolio investment in the age of high imperialism. Explorations in Economic History 13, 283-329.

EDELSTEIN, M. (1982). Overseas investment in the age of high imperialism: the United Kingdom, 1850-1914. New York: Columbia University Press.

EDLINGER, C., MERLI, M. and PARENT, A. (2013). An optimal world portfolio on the eve of World War One: Was there a bias to investing in the new world rather than in Europe? Journal of Economic History 73(2), 498-530.

ELLISON, H. J. (1965). Economic modernization in imperial Russia: purposes and achievements. Journal of Economic History 25, 523-40.

FALKUS, M.E. (1972). The industrialization of Russia 1700-1914. London: Macmillan.

FREEZE, G.L. (1997). Reform and counter reform, 1855-1890. In G.L. Freeze (ed.), Russia. A history. Oxford and New York: Oxford University Press, 170-99.

GARVY, G. (1972). Banking under the tsars and the Soviets. Journal of Economic History 32, 869-93. GATRELL, P. (1982). Industrial expansion in tsarist Russia, 1908-14. Economic History Review 35, 99110.

GATRELL, P. (1994). Government, industry and rearmament in Russia, 1900-1914. Cambridge: Cambridge University Press.

GERSCHENKRON, A. (1947). The rate of growth of industrial production in Russia since 1885. Journal of Economic History 7, 144-74.

GERSCHENKRON, A. (1966). Economic backwardness in historical perspective. Cambridge, MA: Belknap Press of Harvard University Press.

GIRAULT, R. (1972). Conjoncture et investissement international: Les placements français en Russie. Un exemple à la fin du XIXe siècle. Revue économique 23, 889-918.

GIRAULT, R. (1999). Emprunts russes et investissements français en Russie 1887-1914. Paris: Librairie Armand Colin.

GOETZMANN, W. and UKHOV, A. (2006). British investment overseas 1870-1913: a modern portfolio 
theory approach. Review of Finance 10, 261-300.

GOLDSMITH, R. W. (1961). The economic growth of tsarist Russia, 1860-1913. Economic

Development and Cultural Change 9, 441-75.

GROSSMAN, R.S. (2015). Bloody foreigners! Overseas equity on the London stock exchange, 1870-

1913. Economic History Review 68, 471-521.

GREGORY, P. R. (1979). The Russian balance of payments, the gold standard, and monetary policy: a historical example of foreign capital movements. Journal of Economic History 39, 379-400.

GREGORY, P. R. (1994). Before command: an economic history of Russia from emancipation to the first five-year plan. Princeton: Princeton University Press.

HAUTCOEUR, P.C. and ROMEY, C. (2007). Les émetteurs: une hiérachie nouvelle. In P.C. Hautcoeur (ed.), Le marché financier français au XIXº siècle. Paris: Publications de la Sorbonne, 437-94.

JONES, G. and GERENSTAIN, G. (1983). Introduction. In Ol', P.V., Foreign capital in Russia. New York: Garland, V-XXXV.

KAHAN, A. (1967). Government policies and the industrialization of Russia. The tasks of economic history. Journal of Economic History 27, 460-77.

KAHAN, A. (1989). Russian economic history: the nineteenth century. Chicago: University of Chicago Press.

KUZMINA, S. (2015). Syndicat des affaires russes et son rôle dans la formation du complexe militaroindustriel de la Russie à la veille du première guerre mondiale. Quaestio Rossica 4, 145-62.

KIRCHNER, W. (1981). Russian tariffs and foreign industries before 1914: The German entrepreneur's perspective. Journal of Economic History 41, 361-79.

KIRCHNER, W. (1986). Die Deutsche industrie und die industrialisiering Russlands 1815-1914. St. Katharinen: Scripta Mercaturae Verlag.

LAUWICK, M. (1907). L'industrie dans la Russie méridionale. Sa situation - Son avenir. Paris: Misch \& Thron Alcan.

LE BRIS, D. (2013). Why did French savers buy foreign assets before 1914? A decomposition of the 
benefits from diversification. Louvain Economic Review 79, 71-89.

LEROY-BEAULIEU, P. (1905), L'art de placer et gérer sa fortune. Paris: Librairie Ch. Delagrave.

LOWENFELD, H. (1909). Investment. An Exact Science. London: The Financial Review of Reviews.

LYASHCHENKO, P. I. (1970). History of the national economy of Russia to the 1917 revolution. New York: Macmillan.

MARKS, S. (1991). Road to power: The Trans-Siberian railroad and the colonization of Asian Russia, 1850-1917. Ithaca, N.Y: Cornell University Press.

MARKOWITZ, H. (1952). Portfolio selection. Journal of Finance 7, 77-91.

MARTIN, M. (2006). Retour sur "L’abominable vénalité de la Press Française". Le Temps des médias 1, 22-33.

MCKAY, J. P. (1970). Pioneers for profit 1885-1913. Foreign entrepreneurship and Russian industrialization, 1885-1913. Chicago: University of Chicago Press.

METZER, J. (1974). Railroad development and market integration: The case of tsarist Russia. The Journal of Economic History 34, 529-50.

MICHELSON, A. (1965). L'essor économique de la Russie avant la guerre de 1914. Paris: Librairie générale de droit et de jurisprudence.

MICHOTTE, F. (1937). L'évolution des prix de détail en Belgique de 1830 à 1913. Bulletin de l'Institut des Sciences Economiques 8, 346-57.

MILLER, M. (1967). The economic development of Russia 1905-1914 with special reference to trade, industry and finance. London: Frank Cass and Company Limited.

МФРИ (Министерство Финансов Российской Империи). Общая государственная роспись доходов и расходов (1866-1917 годы) [General public state on income and expenses (1866-1917)]. Библиотека 'Исторический бюджет' [http://historylib.minfin.ru/items/browse] [accessed on 06 February 2017].

MOSSE, W. E. (1996). An economic history of Russia, 1856-1914. New York: I.B. Tauris. NEYMARCK, A. (1911). Les finances contemporaines. L'Epargne française et les valeurs mobilières 
1872-1910. Paris: Alcan.

NIZET, B. (1987). Le début des investissements pétroliers belges en Europe orientale (1895-1914). In

E. Stols and M. Dumoulin (eds.), La Belgique et l'étranger auX XIX ${ }^{\circ}$ et XX $X^{\circ}$ siècles. Brussels: Ed. Nauwelaerts, 37-76.

OL', P.V. (1983). Foreign capital in Russia. New York: Garland (translated from the Russian edition of 1922).

OWEN, T. C. (1989). A standard ruble of account for Russian business history, 1769-1914: A Note. Journal of Economic History 49, 699-706.

OWEN, T. C. (1991). The corporation under Russian law 1800-1917: A study in tsarist economic policy. Cambridge: Cambridge University Press.

OWEN, T. C. (1994). La démographie des sociétés anonymes dans l'Empire Russe 1821-1914. In M. Moss and P. Jobert (eds.), Naissance et mort des entreprises en Europe XIXe-XXe siècles. Dijon: Université de Bourgogne, 99-122.

OWEN, T. C. (2013). Measuring business cycles in the Russian empire. Economic History Review 66, 895-916.

PARENT, A. and RAULT, C. (2004). The Influences Affecting French Assets Abroad Prior to 1914. Journal of Economic History 64, 328-62.

PEETERS, W. and WILSON, J. (1999). L'industrie belge dans la Russie des tsars. Liège: Editions Du Perron.

PORTAL, R. (1963). Industriels moscovites: Le secteur cotonnier, 1861-1914. Cahiers du monde russe et soviétique 4, 5-46.

SHARPE, W. F. (1994). The Sharpe ratio. Journal of Portfolio Management 21, 49-58.

STEPANOV, V.L. (2008). Laying the groundwork for Sergei Witte's monetary reform. The policy of finance minister I.A. Vyshnegradsky (1887-1892). Russian Studies in History 47, 38-70.

STOLS, E. (1987). Zuid-Rusland, een vergeten Belgische industriële provincie. In E. Stols and E. Waegemans (eds.), Montagne russe. Belevenissen van Belgen in Rusland. Berchem: EPO, 81-111. 
THORP, W. L. (1926). Business annals. New York: National Bureau of Economic Research.

TOBIN, J. (1958). Liquidity preference as behavior towards risk. Review of Economic Studies 25, 65-86.

TREBILCOCK, C. (1973). British armaments and European industrialization, 1890-1914. Economic History Review XXVI, 254-72.

VAN DE VELDE, G. (1943). Le rendement des Placements 1865-1943. Louvain: Société d'études morales, sociales et juridiques.

VERSTRAETE, M. (1900). Les capitaux étrangers engagés dans les sociétés industrielles en Russie. In A. Neymarck (ed.), Congrès international des valeurs mobilières 4, Paris, 1-39.

VON LAUE, T. H. (1951). The industrialization of Russia in the writings of Sergei Witte. American Slavic and East European Review 10, 177-90.

VON LAUE, T. H. (1954). A secret memorandum of Sergei Witte on the industrialization of imperial Russia. Journal of Modern History 26, 60-74.

VON LAUE, T. H. (1974). Sergei Witte and the industrialisation of Russia. New York and London: Columbia University Press.

WALLER, J. (1979). La naissance du rouble-or. Cahiers du monde russe et soviétique. 20 (3-4), 285304.

WESTWOOD, J. N. (1965). John Hughes and Russian metallurgy. Economic History Review 17, 564-9. WITTE, S. (1921). Mémoires du Comte Witte (1849-1915). Paris: Librairie Plon.

YURICK, E. (1959). The Russian adventure: Belgian investments in imperial Russia. Ph.D. thesis, Ohio State University. Reproduction: Ann Arbor, Michigan: University Microfilms International. 
Table 1. Number of companies listed at the BSE with main activity outside Belgium by country (whole period 1880-1914; 1914 only)

\begin{tabular}{|l|c|c|l|c|c|}
\hline Country & $1880-1914$ & 1914 & Country & $1880-1914$ & 1914 \\
\hline Russia & 134 & 81 & Netherlands & 16 & 10 \\
\hline France & 66 & 52 & Luxembourg & 14 & 7 \\
\hline Italy & 44 & 32 & Romania & 14 & 11 \\
\hline Spain & 43 & 30 & Argentina & 13 & 11 \\
\hline Congo (Belgian) & 33 & 26 & Egypt & 13 & 13 \\
\hline Germany & 27 & 11 & Bresil & 12 & 6 \\
\hline Austria-Hungary & 18 & 9 & OTHERS & 63 & 42 \\
\hline
\end{tabular}

Source: SCOB database, based on the Brussels Stock Exchange, Cours authentique de la Bourse de Bruxelles, 1880-1914. 
Table 2. Total returns for all Russian BSE-listed stocks and Belgian BSE listed stocks (1880-1914) (1 January $1880=100$ )

\section{Russian BSE stocks}

\begin{tabular}{|c|c|c|c|c|c|c|c|c|}
\hline Period & & Real & & & Jominal & & & \\
\hline & $\begin{array}{c}\mathrm{GM}^{\mathrm{a}} \\
(\%)\end{array}$ & $\begin{array}{c}\mathrm{AM}^{\mathrm{b}} \\
(\%)\end{array}$ & $\begin{array}{c}\mathrm{STD}^{\mathrm{c}} \\
(\%)\end{array}$ & $\begin{array}{l}\mathrm{GM}^{\mathrm{a}} \\
(\%)\end{array}$ & $\begin{array}{c}\mathrm{AM}^{\mathrm{b}} \\
(\%)\end{array}$ & $\begin{array}{c}\text { STD }^{c} \\
(\%)\end{array}$ & $\begin{array}{l}D^{d} \\
(\%)\end{array}$ & SHARPE $^{\mathrm{e}}$ \\
\hline $1880-89$ & 10.06 & 11.57 & 17.22 & 8.07 & 9.13 & 16.07 & 5.09 & 0.35 \\
\hline 1890-99 & 6.33 & 6.54 & 8.09 & 5.35 & 5.52 & 8.18 & 3.91 & 0.40 \\
\hline $1900-09$ & -6.64 & -5.16 & 17.30 & -5.36 & -4.51 & 13.45 & 3.19 & -0.59 \\
\hline 1910-14 & 7.54 & 8.34 & 15.19 & 11.40 & 12.14 & 12.85 & 3.74 & 0.76 \\
\hline $1900-07$ & -9.56 & -8.04 & 17.82 & -8.00 & -7.21 & 13.30 & 3.24 & -0.77 \\
\hline 1895-99 & 4.22 & 4.26 & 7.22 & 3.49 & 3.54 & 7.49 & 3.67 & 0.21 \\
\hline 1880-1914 & 3.63 & 4.89 & 16.26 & 3.74 & 4.63 & 14.49 & 4.02 & 0.13 \\
\hline 1890-1914 & 1.17 & 2.22 & 15.02 & 2.06 & 2.83 & 13.34 & 3.59 & -0.01 \\
\hline \multicolumn{9}{|c|}{ Belgian BSE stocks } \\
\hline $1880-89$ & 5.44 & 5.92 & 8.50 & 3.53 & 4.08 & 9.29 & 4.02 & 0.07 \\
\hline 1890-99 & 6.62 & 6.80 & 4.25 & 5.64 & 5.76 & 4.32 & 4.47 & 0.21 \\
\hline 1900-09 & 5.19 & 6.12 & 13.49 & 6.64 & 7.09 & 10.02 & 4.61 & 0.55 \\
\hline 1910-14 & -1.83 & -1.74 & 5.64 & 1.70 & 1.77 & 4.81 & 3.96 & -0.29 \\
\hline 1900-07 & 3.79 & 4.80 & 14.47 & 5.58 & 6.04 & 10.54 & 4.64 & 0.37 \\
\hline 1895-99 & 9.68 & 9.75 & 3.28 & 8.91 & 8.96 & 3.42 & 4.09 & 1.71 \\
\hline
\end{tabular}




\begin{tabular}{lllllllll}
$1880-1914$ & 4.63 & 5.13 & 9.20 & 4.74 & 5.09 & 7.86 & 4.31 & 0.33 \\
$1890-1914$ & 4.31 & 4.82 & 9.45 & 5.23 & 5.50 & 7.22 & 4.42 & 0.12 \\
\hline
\end{tabular}

Notes:

${ }^{a} \mathrm{GM}$ : Time-weighted rate of return as measured by geometric average.

${ }^{\mathrm{b}} \mathrm{AM}$ : Average of returns as measured by arithmetic average.

'STD: Volatility as measured by the standard deviation.

${ }^{\mathrm{d}}$ DY: Dividend Yield

e SHARPE: annualised Sharpe ratio, i.e. the average excess return divided by its standard deviation. Source: SCOB database, based on the Brussels Stock Exchange, Cours authentique de la Bourse de Bruxelles, 1880-1914.

Table 3: Annualised statistics optimal portfolios, January 1880 - July 1914.

\begin{tabular}{rcccc}
\hline & Belgian Equity & $\begin{array}{l}\text { Russian } \\
\text { Equity }\end{array}$ & $\begin{array}{l}\text { Tangency } \\
\text { portfolio (TP) }\end{array}$ & $\begin{array}{l}\text { Minimum } \\
\text { variance } \\
\text { portfolio } \\
\text { (MVP) }\end{array}$ \\
\hline Average excess return & $1.92 \%$ & $1.65 \%$ & $1.91 \%$ & $1.90 \%$ \\
Standard deviation & $6.02 \%$ & $13.16 \%$ & $5.95 \%$ & $5.94 \%$ \\
Sharpe ratio & 0.320 & 0.125 & 0.321 & 0.321 \\
Weight in TP & $95.50 \%$ & $4.50 \%$ & & \\
\hline Weight in MVP & $92.42 \%$ & $7.58 \%$ & & \\
\hline
\end{tabular}

Source: SCOB database, based on the Brussels Stock Exchange, Cours authentique de la Bourse de Bruxelles, 1880-1914.

Note: The tangency portfolio (TP) is the portfolio that maximises the Sharpe ratio, whereas the minimum variance portfolio (MVP) is the portfolio that minimises portfolio risk regardless of expected return. The Sharpe ratio is found by dividing the average excess return by the standard deviation of returns. 
Figure 1. IPOs, delistings and total number of Russian BSE stock-quoted companies (1880-1914)

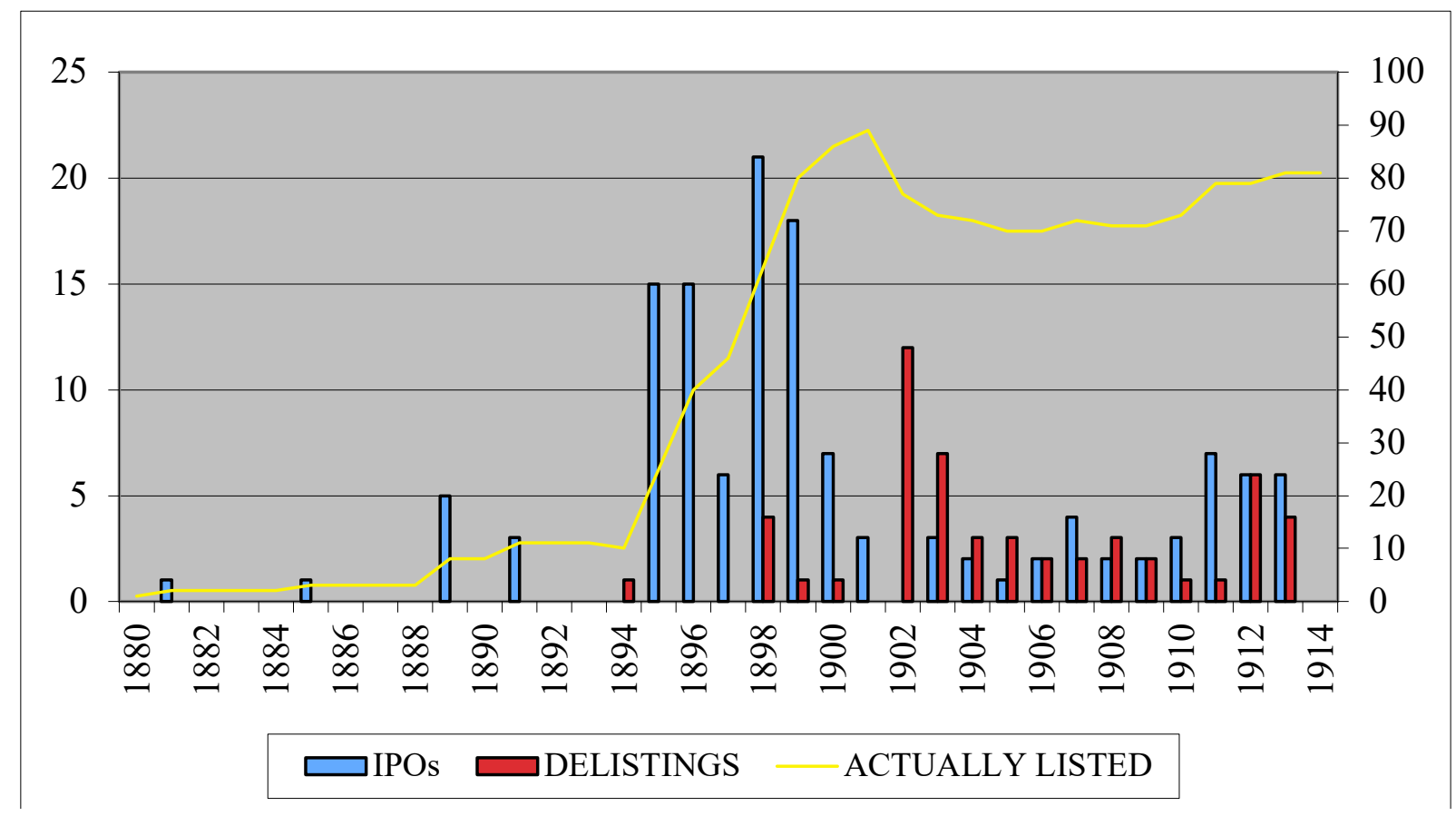

Source: SCOB database, based on the Brussels Stock Exchange, Cours authentique de la Bourse de Bruxelles, 1880-1914.

Note: IPOs are defined as the first time a company enters the stock market with a new stock. Delistings relate to the day a company no longer has any stock on the stock exchange. Companies with only bonds do not feature in the graph. 
Figure 2. Price index Russian BSE-listed stocks and Belgian BSE listed stocks 1889-1914 (nominal data) (common stock only) (31 December $1889=100$ )

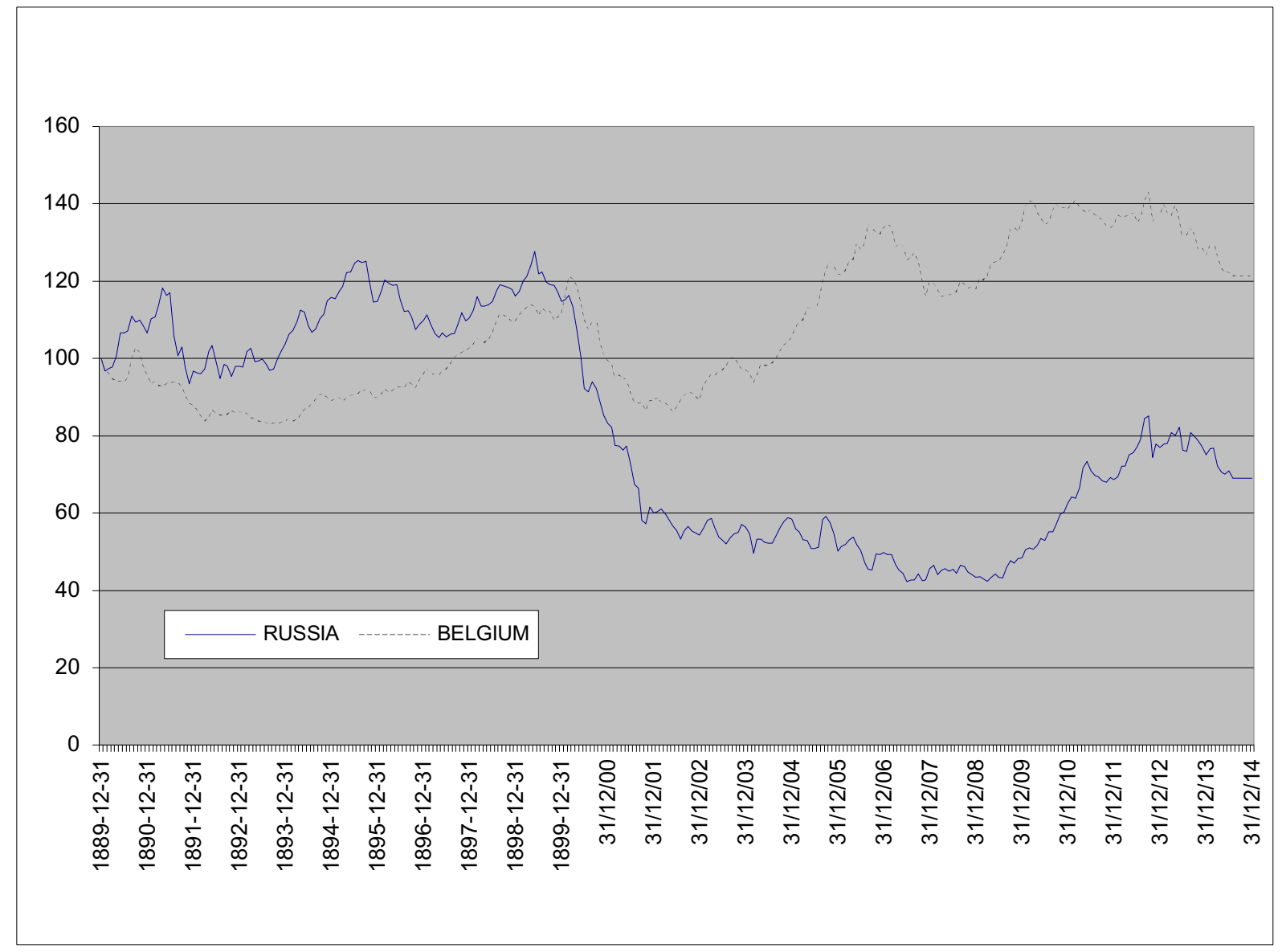

Source: SCOB database, based on the Brussels Stock Exchange, Cours authentique de la Bourse de Bruxelles, 1880-1914.

Note: Russia $=$ Russian BSE-listed stocks; Belgium = Belgian BSE listed stocks 
Figure 3: The efficient frontier, the Capital Allocation Line and the Tangency Portfolio.

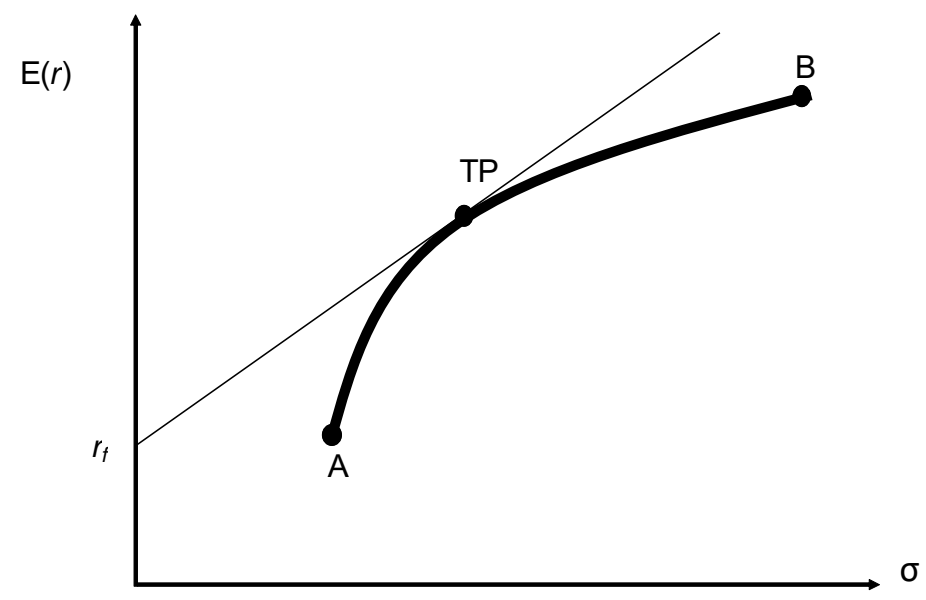

Note: The thick concave line A-TP-B denotes the mean-variance efficient frontier: it shows all portfolios the maximise expected return $E(r)$ for a given risk as measured by the standard deviation of returns $\sigma$. The straight line is the Capital Allocation Line (CAL). It starts at the return of the riskless asset $r_{f}$ and is tangent to the efficient frontier. Where the CAL intersects the efficient frontier, we find the tangency portfolio (TP). 
Figure 4. Correlation and MVP portfolio (1890-1914) based on rolling samples of 120 months.

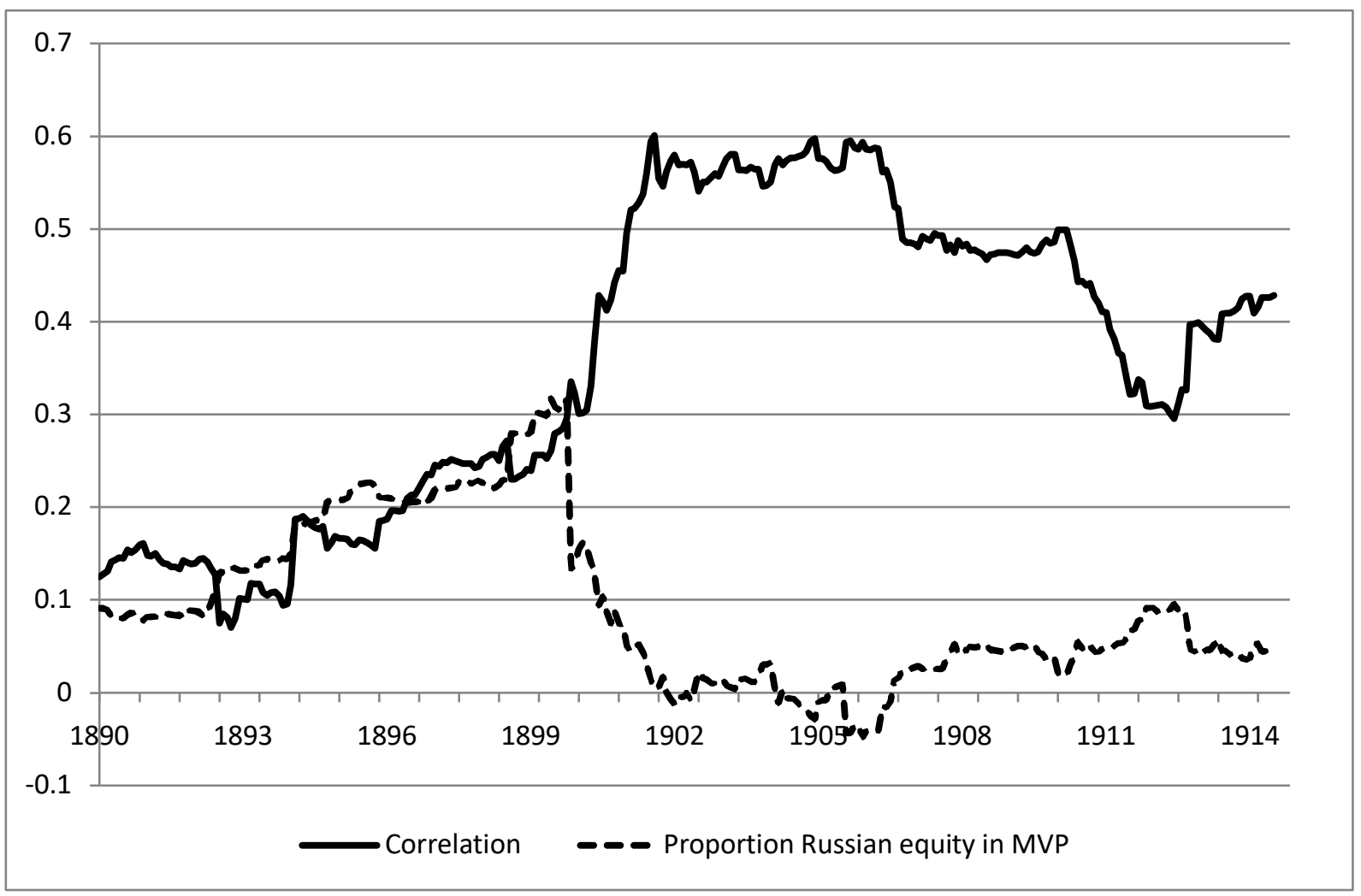

Source: SCOB database, based on the Brussels Stock Exchange, Cours authentique de la Bourse de Bruxelles, 1880-1914.

Note: The $\mathrm{x}$-axis (time axis) indicates the month at which the ten-year correlation could have been computed by contemporaneous investors; the $y$-axis indicates the correlation coefficients over rolling samples of 120 months. 
Acknowledgments: The authors are highly indebted to Marc Deloof and Ali Parry for their comments and suggestions. We thank the editor and the anonymous referees for their constructive comments, which helped us to improve the manuscript. All remaining errors are ours. 


\footnotetext{
${ }^{i} A$ list is available from the authors upon request.

ii Belgium was in 1913 the third most industrialized country following the USA and the UK (Bairoch 1982, p. 286). It was the sixth most important country around 1902 in terms of stock and bond capitalisation per capita (Neymarck 1911, p. 442).

iii Russia did everything for its reputation such as spending huge amounts of money to foreign newspapers in order to promote Russia. It favoured transparency by publishing the annual state budget from 1866 onwards (МФPИ, 1866-1917).

iv Foreign capital flows involves capital flows from one country to another. It can take the form of loans or stocks.
}

${ }^{\vee}$ The first paper currency was the assignation ruble, which was used from 1769 until 1849. The credit ruble was the paper currency that replaced the assignation ruble in 1841. It was convertible to silver until late 1863, after which the credit ruble declined in terms of gold until the introduction of the gold standard in 1897.

vi However it seems that portfolio investors were not impressed by that alliance as they were primarily interested in high returns and a diversified portfolio. The question is heavily debated. For example, Parent and Rault (2004) refute the thesis that French capital exports were motivated by diplomatic and political factors. They state French foreign investment at the time was driven by economic and financial considerations only.

vii According to Catin the total amount of all French loans for Russia was 13.2 billion Francs in 1914 while French nominal capital for all private companies was 1.7 billion Francs (Catin 1927, p. 128; see also Bovykin 1990; Hautcoeur and Romey 2007, pp. 469-72).

viii Arthur Raffalovitch (1853-1921) an economist and Russian diplomat paid enormous amounts to the press to write articles promoting investment in Russia (Martin 2006).

ix See for example the article “Les grandes usines du midi de la Russie” (10 January 1895).

${ }^{x}$ The (widely used) data of Pavel Ol' (Ol' 1983) report for all corporations their nominal (foreign) 
capital (but do not measure real investments). Jones and Gerenstain (Jones and Gerenstain 1983) provide an extensive discussion of these data. According to Carstensen Russia did not import much capital once all the elements of the balance of payments were accounted for (Carstensen 1983, p. 143-7; Carstensen 1977).

${ }^{x i}$ The value of the ruble was evolving until 1897 when it was stabilised at 1 ruble $=2.67$ BEF (with $1 \mathrm{f}$ $=25 \mathrm{BEF}$ and $1 \$=5 \mathrm{BEF}$ ). For these data McKay used also Eventov [Эвентов Л.Я. Иностранный капитал в русской промышленности. Moscow-Leningrad, 1931]

xii Before 1897 some companies had their share capital in paper rubles, others in gold rubles. In 1886 the share capital of Dniéprovienne consisted of 10,000 shares of 500 paper rubles. In 1897 companies with their capital in paper rubles had to convert it in gold rubles.

xiii We use the term IPO when a stock is first traded on the BSE.

xiv The Recueil Financier was an annual publication (1893-1975) providing extensive information about all stock-quoted companies.

${ }^{x v}$ Or as Girault has put it "Le cours en bourse est un fait primordial pour une société; normalement la valeur de l'action traduit la vie de la société, exprimant ses réussites par des hausses, ses difficultés par des baisses; on sait d'autre part que la spéculation peut anticiper les résultats futurs par un mouvement ascendant ou descendant excessif" (Girault 1999, p.79)

xvi This conclusion also holds for the Belgian stock returns in this period, see Annaert, Buelens \& De Ceuster (2012).

xvii We add delistings to show how high the mortality rate was for all of these investments. The high number of delistings can help to understand the low returns for the overall period (see further on). xviii As Chambers indicated "IPOs have a tendency to occur in waves (..)" (Chambers 2010, p.60) xix 1910-14 is, of course, not a decade but the analysis ends in 1914 as the BSE was closed during the First World War.

${ }^{\mathrm{xx}}$ The Sharpe ratio is an indicator of the return-risk trade-off: the higher it is, the more return is offered per unit of risk as measured by the standard deviation of returns. See section VII for more 
details.

${ }^{x \times i}$ Stocks had a volatility of 17.4 per cent around a long-term moving average during 1900-2014

(Dimson, Marsh, and Staunton 2015, p. 12)

xxii The world average for 1900-2014 was around 5.2 per cent (Dimson, Marsh, and Staunton 2015, p. 189).

xxiii See for example, Lowenfeld (1909) and Neymarck (1911). More references can be found in Edlinger et al. (2013) and Chambers and Esteves (2014).

${ }^{\text {xxiv }}$ More specifically, the proportion of Russian shares in the TP is given by (Bodie, Kane \& Marcus 2014, p. 217):

$$
\frac{E\left(R_{R}\right) \sigma_{B}^{2}-E\left(R_{B}\right) \rho \sigma_{B} \sigma_{R}}{E\left(R_{R}\right) \sigma_{B}^{2}+E\left(R_{B}\right) \sigma_{E}^{2}-\left[E\left(R_{B}\right)+E\left(R_{R}\right)\right] \rho \sigma_{B} \sigma_{R}}
$$

where $E(R)$ denotes an expected return in excess of the riskless rate of return, $\sigma$ the standard deviation of returns, and $\rho$ the correlation between Belgian and Russian stock returns. The subscripts $R$ and $B$ point toward Russian and Belgian stocks, respectively. Of course, the proportion of Belgian shares is one minus the proportion of Russian shares.

${ }^{x x v}$ The short rate was calculated based on the commercial paper rates as published in the official quotation lists of the Antwerp Stock Exchange and the newspaper Moniteur des Intérêts Matériels. xxvi To account for non-synchronicities between Belgian and Russian equity returns, we also computed a robust correlation coefficient. This always yielded very similar results, so we only report the simple correlation coefficients for comparative purposes.

xxvii The analysis is a kind of stress test. Using the realized returns shows that the tangency portfolio does not invest a lot in Russian equity. But we know that average returns are very volatile and it may take many decades before they start to converge toward the expected return investors used. Moreover, the composition of the tangency portfolio is very sensitive to the expected return input. Therefore, we built an efficient portfolio that does not depend on expected returns, the minimum variance portfolio. Economically, this means that we assume that investors do not make a distinction 
with regards of expected returns across assets. Russian equity and Belgian equity are seen as equivalent from an expected return perspective. This allows us to solely focus on the diversification potential Russian equity has for a purely Belgium-oriented investor.

xxviii This situation would imply that in Figure 3 the efficient frontier collapses into the single point $\mathrm{A}$. All other risky assets would plot to the right of $A$.

${ }^{\text {xxix }}$ Results based on 60 month samples are qualitatively similar. 